\title{
牛乳のラクトフォリン:その発見，特性および機能
}

菅野長右土閒

宇都宮大学農学部，宇都宮市 321

\section{Lactophorin from Bovine Milk Whey : Its Finding, Characterization and Function}

\author{
Choemon Kanno \\ Department of Animal Science, Utsunomiya University, \\ Utsunomiya-shi 321
}

Key words : lactophorin, milk fat globule membrane, proteose-peptone, milk

ラクトフォリン (Lactophorin, LP) は, 牛乳の乳 脂肪球皮膜 (MFGM) の可溶性糖蛋白質 (SGP) の抗 体と反応し，かつホエーのプロテオースペプトン（PP） 画分に存在する耐熱性のタンパク質で, 多形性の構造を あつ糖蛋白質に，著者によって付けられた名称である ${ }^{40)}$. ここでは，LP と密接に関係している MFGM， それの 一構成成分である SGP, SGP と同一の抗原性をもつ LP を含む PP， そして LP の発見，特性，起源，機能 について概説する.

\section{1. 乳脂肪球皮膜}

BARGMANN and $\mathrm{KNOOP}^{5)}$ によって, 釈腺細胞で合 成された脂肪滴は成長しつつ頂端細胞膜側まで運ばれ， そこで頂端細胞膜で被覆され, 細胞外に分泌されること が電顕で最初に観察されている。この乳脂肪球を被覆し， 脂肪と水の界面を形成している膜物質を MFGM と呼 んでいる. 細胞膜の細胞外への離出現象は生物界でも乳 腺のみにみられる現象で, ホルスタイン種の牛乳の乳脂
肪 $1 \mathrm{~g}$ 当たりの表面積は $2 \mathrm{~m}^{2}$ であり, 乳牛が乳脂肪率 $3.5 \%$ の牛乳を 1 日当り $25 \mathrm{~kg}$ 泌乳しているとすると， 1 日に $1,750 \mathrm{~m}^{2}$ の細胞膜を離出していることになり， その補修機構が備わっていると言えども，乳分泌による 母体へのエネルギ一要求は莫大なものである，MFGM の生成機構や構造の詳細については, PATTON and KEENAN $^{78)}$, 菅 野5), MCPHERSON and KITCHEN ${ }^{693}$, KEENAN ら ${ }^{59,61)}$, KANNO ${ }^{43)}$ の総説を参照して頂きたい，

MFGM は，基本的には細胞内で脂肪滴を被覆してい た 2 分子構造をすたない膜に由来する内膜 ${ }^{14,15)}$ と細胞 膜に由来する外膜の二層から構成されている ${ }^{94)}$. MFGM 生成における一つの特街は, 分泌直後の脂肪球は完全に 細胞膜で被覆されているが, 分泌後の時間の経過ととも に脂肪滴を被覆した細胞膜（=MFGM）の大半は脂質 二重層の構造を維持しつつる，一部は無構造となり，乳 脂肪球から離脱してしまうことである。これは，分泌後， 細胞内の脂肪滴の表層にあるりん脂質層之細胞膜の内側 のりん脂質層とが融合し，膜を構成する成分が再配列さ

略号 : LP, ラクトフォリン; MFGM，乳脂肪球皮膜；SGP，可溶性糖タンパク質；PP，ブロテオースペプトン; $\mathrm{PPC}-3 ，-5,-8$, それぞれ PP のコンポネント-3，-5，-8 画分; Glc，グルコース；Gal，ガラクトース; Man, マンノース; Fuc, フコース; GlcNAc, $N-$ アチルグルコサミン; SA, シアル酸; GalNAc, $N$-アセチルガ ラクトサミン; TG, トリアシルグリセロール；PAGE，ポリアクリルアミド電気泳動；SDS-PAGE, ドデシル 硫酸ナトリゥム存在下での PAGE；LPL, リポプロティンリパーゼ; Mr, 分子量 
れる結果, 過剩となった被覆細胞媨が小胞化あるいは断 片化して乳脂肪球から脱離され，脂肪球は安定化され る ${ }^{43)}$. 離脱した膜画分は, 超遠心分離によってスキムミ ルク膜画分として分画することができる。このような分 布割合はクリームとスキムミルク膜画分の細胞膜標識醇 菜活性 ${ }^{56)}$ およびりん脂質 ${ }^{64,77)}$ や精脂質 ${ }^{911}$ の含量の分布 から推測でき，スキムミルク膜画分における細胞膜の標 識酵素の活性は全乳の $30-40 \% ， り$ ん脂質は $30-50 \%$ ， 糖脂質は $41 \%$ を占めている。

生成機序におけるもう一つの問題点は, ウシ MFGM で一部の主要な傏蛋白質（特に PAS-1〜-7のうちの PAS-1，-5，-6，-7）がゥシ乳腺の細胞膜画分に検出 できないことである ${ }^{44 \sim 46)}$.このことはラットの乳腺の細 胞膜とその MFGM でも報告されている30,31,62). しか し，キサンチンオキシダーゼや PAS-5（ブチロフィリ ン)の標識抗体は乳腺細胞の頂端部に観察されてお

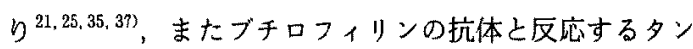
パク質が細胞内脂肪滴のコート物質に見出されてお $り^{14,16)}$ ，MFGM を構成するタンパク質の複雑さを示し ている.MFGM の形成には細胞内脂肪滴のコート物 質, 分泌小胞膜, 頂端細胞膜, 細胞内コート物質等が関 与していると考えられるようになってきているので43， MFGM と乳腺細胞膜における主要ポリベプチド組成の 差異の原因もますなく明らかになるであるう。

単離された牛乳の MFGM は約 $45 \%$ のタンパク質と 55\%の脂質から構成されている. MFGM における夕 ンバク質と脂質の割合は，調製法，特に，破壊されなか つた微小脂肪球の除去の有無あるいは乳脂肪球を物理的 に破壊した時に MFGMに随伴してくる高融点の TG の量によって変動する゙7). 従って、チャーニングによっ て調製した MFGM の TG は全脂質の約 69\% (50-85 $\%$ ）を占めてお施り，27\%（24-40\%）がりん脂質，3\% がコレステロール，残りが糖脂質等である．りん脂質の 組成はホスファチジルコリン(27\%)，ホスファチジル エタノールアミン (33\%), スフィンゴミェリン (23\%), ホスファチジルセリン $(8 \%)$, ホスファチジルイノシト 一ル $(7 \%)$ である ${ }^{55)}$. 情脂質のうち, SA $\alpha 2 \rightarrow 8 \mathrm{SA} \alpha$ $2 \rightarrow 3 \mathrm{Gal} \beta 1 \rightarrow$ Ceramide の構造をもつ GD 3 が $67 \%$ を占めている、また（Gal $\beta 1 \rightarrow 4 \mathrm{GlcNAc} \beta 1 \rightarrow 6)(\mathrm{SA}$ $\alpha 2 \rightarrow 6 \mathrm{Gal} \beta 1 \rightarrow 4 \mathrm{GlcNAc} \beta 1 \rightarrow 3$ ) Gal $\beta 1 \rightarrow 4 \mathrm{Glc} \beta$ $1 \rightarrow$ Ceramide の分岐した構造をむつラクトマンマ系列 ガングリネシドが新しく見出されている ${ }^{90 ?}$.

牛乳の MFGM のタンパク質部には，4-30\% アクリ ルアミド濃度勾配のついた SDS-PAGEで, Mr $13 \mathrm{~K}$ 〜210K の約 42 本のポリペプチドが検出される ${ }^{55}$. そ
の内の主要なポリペプチドには，タンバク質染色で検出 されるバンドが 16 本 (CB-1 CB-16), 糖染色で検出 されるバンドが7本（PAS-1 PAS-7）ある.これま でこれらのバンドに統一された名称がなく，研究者に上 って検出されたバンドの移動度の小さい順に番号が付さ

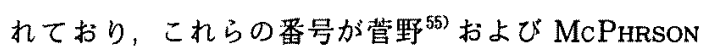
and $\mathrm{KITCHEN}^{69)}$ によってまとめられている. PAS-1 (Mr $100 \mathrm{~K}), \quad$ PAS-2 (Mr 96 K), PAS-3 (Mr $90 \mathrm{~K})$ のバンドは Coomassie brilliant blue $\mathrm{R}-250$ では検 出できない. PAS-6 (Mr 53 K 59 K) と PAS-7 (Mr $48 \mathrm{~K} \sim 55 \mathrm{~K})$ は非常に近似した分子量をもつが，前者 はコンカナバリン A に対して親和性を示すが, 後者は 示さないので区別することが出来る ${ }^{39}$. また乳腺細胞の 細胞膜およびその他のサブオルガネラ由来の榅識醉素等 が多数存在している 59 69, 78).これまでに単離され，その 性質が明らかにされている牛乳の MFGM のポリペプ チドは，CB-1 (Mr 155 K，キサンチンオキシダーゼ) ${ }^{9}$, PAS-4 $(\mathrm{Mr} 80 \mathrm{~K} \sim 85 \mathrm{~K})^{25)}$ と PAS-5 $(\mathrm{Mr} 67 \mathrm{~K} \sim 75$ $\mathrm{K})^{22,60)}$ のみである. PAS-5 はブチロフィリン (butyrophilin）之命名されている ${ }^{21,29)}$.人釈では, 高分子量 糖タンパク質 ${ }^{85,86}$ ， EPG-70 (牛乳の PAS-5 に相当, Mr $70 \mathrm{~K})^{322}$, EPG-155 (Mr $\left.155 \mathrm{~K}\right)$, EPG-39 (Mr 39 $\mathrm{K})^{33)}$ が単離・精製されている. MFGM は糖タンパク 質に富むが，その糖銷の構造については報告がない，

\section{2. 可溶性糖蛋白質}

可溶性糖蛋白質 (SGP) は MFGM の構成タンパク 質の一つで, MFGM タンパク質の約 $5 \%$ を占める. MFGM の低密度画分をクロロホルム/メタノール湿液 $(2: 1, \mathrm{v} / \mathrm{v})$ で脱脂後に $0.02 \mathrm{M} \mathrm{NaCl}$ 溶液に可溶な タンパク質画分を Bio Gel A-5 m でのゲル滤過によ って，PAGEで単一なバンド捛よび沈降分析で対称な 一つのピークを示すタンパク質として単離・精製されて いる ${ }^{51)}$.このタンパク質は約 $31 \%$ の糖を含み，ての内 の $14 \%$ がへキンース，8.1\%がへキソサミン，8.0\%が SA, $0.8 \%$ が Fucである. SGP の物理化学的パラメ ーターを Table 1 に示す. SGP は SDS-PAGE では $\mathrm{Mr} 10 \mathrm{~K}$ から $88 \mathrm{~K}$ の 8 本のポリペプチドに解離され $3^{83}$. その内, 7 本は過ヨウン酸シッフ試葲 (PAS) で 染色される (PAS-I〜-VII). PAS-II〜-VII は移動度 において MFGM の主要糖ぺプチド（PAS-1〜-7）と は異なるが, PAS-I (Mr $88 \mathrm{~K})$ は PAS-1 と相似し ている. 主要なペプチドは PAS-IV とVで，その分子 量は $20 \mathrm{~K}$ と $17 \mathrm{~K}$ である. トリプシンによって $\mathrm{PAS}^{-}$ II と一III 以外は消化されやすく, PAS-VII $(\mathrm{Mr} 10 \mathrm{~K})$ 
牛乳のラクトフォリン: その発見, 特性および機能

Table 1. Physical-chemical Properties of Soluble Glycoprotein (SGP) Isolated from Bovine Milk Fat Globule Membrane

\begin{tabular}{llc}
\hline \hline Molecular weight (Mr) & $\mathrm{K}$ dalton & 139 \\
Sugar content & $\%$ & 31 \\
Isoelectric point & $\mathrm{pl}$ & $4.4-5.7$ \\
Sedimentation velosity & $\mathrm{S}_{20, \mathrm{w}}^{\circ}$ & 6.10 \\
Diffusion constant & $\mathrm{D}_{20, \mathrm{w}}^{\circ}$ & 3.79 \\
Partial specific volume & $\overline{\mathrm{v}}, \mathrm{m} / \mathrm{g}$ & 0.715 \\
Frictional ratio & $\mathrm{f} / \mathrm{f}_{0}$ & 2.16 \\
Absorption coefficient & $\mathrm{E}_{1 \mathrm{~m}, 280 \mathrm{~nm}}^{1 \%} 1.84$ \\
Constituent polypeptide & & \\
$\quad$ Number & $\mathrm{K}$ dalton & $10-88$ \\
$\mathrm{Mr}$ & $\mathrm{K}$ dalton & 17,20 \\
$\mathrm{Mr}$ of majoar polypeptide
\end{tabular}

は消化物の移動度とも一致している。

ここで得られた SGP の性質はJACKSON ら ${ }^{34)}$ お び SWOPE ら ${ }^{891}$ によって報告されている糖タンパク質の 糖含量, 沈降係数，分子量が暴なり，その差は脱脂法と 抽出法に起因している ${ }^{95)}$ ，すなわち，硫安程析物をエ夕 ノール/エーテル $(35: 65, v / v)$ で脱脂したり ${ }^{34)}$ ，ある いはメタノール/クロロホルムで脱脂しても, 高塩溶液 (1 M KCl) で抽出すると ${ }^{89}$ ，MFGM の主要糖ぺプチ ド（PAS-4，-6，-7）が湿入し，糖含量も低下してい る. 特にエ夕ノール/エーテルで脱脂した場合には脂質 結合性りん含量が高く，約 $9 \%$ のりん脂質が含まれてお $り^{95)}$ ，分子間結合を複雑にし，大きな沈降係数 $\left(\mathrm{S}_{20} \mathrm{w}\right.$ 9.0）を与える要因になっている.

$\mathrm{SGP}$ のI $\mathrm{pH} 4.4$ から 5.7 の広いバンドを形成す るが，このバンドを 5 等分してタンパク質を抽出して SDS-PAGE を行なうと，構成ポリペプチドの量的差 異が認められる ${ }^{522}$. SGP の Mr は $139 \mathrm{~K}$ と算出され ているが，SDS-PAGE で解離されたボリペブチドの 総和はこれを越えてしまうことからあ推察されるように， SGP 分子は多分散性である。.さらに，SGP に対する 多価抗体に対して免疫拡散法では各 1 本の主沈降線とマ イナーな沈降線が観察され，免疫電気泳動法ではほぼ移 勤度の同じ 4 本の沈降線が観察される ${ }^{52)}$.これらのこ上 から, SGP は免疫学的には不均一であり ${ }^{13)}$, 多分散性 の糖タンパク質の性犋を持っている.

\section{3. プロテオースペプトン}

プロテオースペプトン（PP）は，熱に安定で，酸性 (pH 4.6) で可溶だが，12\%トリクロール酢酸23,82,92) に不溶な、りんを含む糖タンパク質の混合物であると定 義されている ${ }^{93)}$. 脱脂乳を $95^{\circ} \mathrm{C}$ で $20-30$ 分加熱後 $30^{\circ} \mathrm{C}$
まで冷却し，pH 4.6 で沈段するカぜインや熱变性タン パク質を除去後の上清の非透析性物質が PP である，PP 含量はホエータンパク質の 18-25\% および全タンパク質 の約 $4 \%$ である ${ }^{81}$ ，この画分の主要成分は，ホエータン パク質の自由界面電気泳動 (ベロナール緩衝液, $\mathrm{pH} 8.6$, イオン強度 0.1）での移動度の增す順に, コンポネントー 3 (PPC-3), -5 (PPC- 5 ), -8 (PPC-8) 上 LARSON and ROLLERI ${ }^{68)}$ によって名付けられている，同様な移 動度の順位はアルカリ性激粉一尿素電気泳動や PAGE でも報告されているか，もっと不均一である ${ }^{66)}$. PP は 加熱処理によって生成されるものでないことは RowLAND $^{82)}$ を初めとして多くの研究者によって確認されて いる

PPC-5 は 0.96\%のりん含量上 $10.5 \%$ のプロリン含 量から $\beta$-カゼインとの類似性が当初から指摘されてい た ${ }^{67)}$. PPC-8 は Bio Gel P-10でのゲル濾過によって 2 画分に分画することができ，それらのPAGEでの移 動度加ら PPC-8-fast (F) と PPC-8-slow (S) と名 付りられた ${ }^{67}$. 両者はりん含量が高、（それぞれ $2.8 \%$ 上 $2.1 \%), \mathrm{Mr}$ もそれぞれ $4.1 \mathrm{~K}$ と $9.9 \mathrm{~K}$ と概算され ていた ${ }^{67)}$. その後, $\beta$ ーカゼインの一次構造の解明に之 屯なって ${ }^{26,80)}, \gamma$ 一ガセイン (29-209, 105-209, 107209）は $\beta$-カゼインのプラスミンによる蛋白分解によ って生じる ${ }^{19,39)} \mathrm{C}$-末端側のフラグメントであるのに対 して ${ }^{24,27,28)}, \mathrm{PPC}-5$ と PPC-8 F は $\beta$-カゼインの N末端側のフラグメントであることが明らかにされている (Fig. 1).すなわち，PPC-8 F は $\beta$ ーカゼインの1-28 残基 ${ }^{3)}, \mathrm{PPC}-5$ は 1-105 おょび 1-107 残基であり ${ }^{2,17)}$, PPC-8 S は29-105 および 29-107 残基のフラグメント である ${ }^{20)} . \mathrm{PPC}-8 \mathrm{~F}$ は $\mathrm{pH} 6.6$ で高い荷電をむち，低 分子量で， 4 残基の Ser-P を有し，芳香族了ミ儿酸を 含まない (Table 2).

PPC-5 よ-8 はホエーとカゼインの両画分に存在して

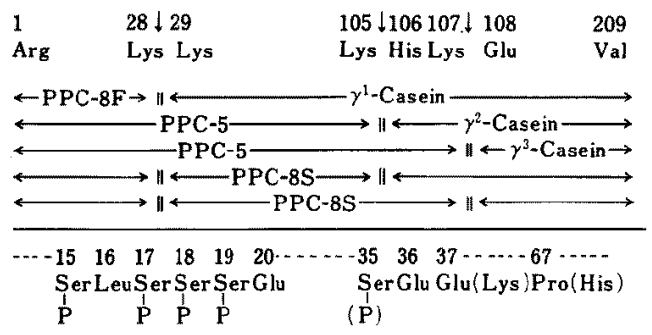

Fig. 1. Relationship of proteose-peptone component5 (PPC-5), -8-fast (PPC-8 F) and -8-slow (PPC-8 S) and the primary structure of $\beta$-casein $\mathrm{A}^{2}$ in bovine milk. 
Table 2. Physical-chemical Characteristics of Proteose-peptone Components (PPC) Calculated from the Composition

\begin{tabular}{lcccccc}
\hline $\begin{array}{l}\beta-\text { Casein } \\
\text { and Proteose- } \\
\text { peptone }\end{array}$ & Fragment & $\begin{array}{l}\text { Charge at } \\
\mathrm{pH} \mathrm{6.6}\end{array}$ & $\begin{array}{l}\text { Ionic } \\
\mathrm{pH}\end{array}$ & $\begin{array}{l}\text { Partial } \\
\text { specific } \\
\text { volume }\end{array}$ & $\begin{array}{l}\text { Absopti- } \\
\text { vity at } \\
280 \mathrm{~nm}\end{array}$ & $\begin{array}{l}\text { Molecular } \\
\text { weight }\end{array}$ \\
\hline $\begin{array}{l}\beta \text {-Casein A } \\
\text { PPC-5 }\end{array}$ & $1-209$ & -12.3 & 5.19 & 0.742 & 0.46 & 23,980 \\
& $1-105$ & -14.4 & 4.55 & 0.729 & 0.11 & 12.176 \\
PPC-8F & $1-28$ & -10.5 & 3.0 & 0.697 & 0 & 3,473 \\
PPC-8S & $29-105$ & -4.1 & 5.2 & 0.742 & 0.16 & 8,716 \\
& & & & & & $(8,981)^{*}$ \\
\hline
\end{tabular}

*, Values for genetic variant and see the legend of Fig. 1.

いるが, PPC-3 はホエー画分にのみ存在し, 当初は血 液由来であるとされていた ${ }^{66)}$. NG ら ${ }^{72)}$ は, PPC-3 は 約 $17 \%$ の糖を含み, $\operatorname{Mr} 163 \mathrm{~K}$ で, $5 \mathrm{M}$ グアニジン塩 酸で解離したペプチドの $\mathrm{Mr}$ は 22-44 K の不均一な夕 ンパク質であると報告している、 PPC-3 の主要糖タン パク質が LP である.

人乳にも牛乳とほぼ同量の PP が含まれており，そ の糖含量は平均 $45 \%$ で, 牛乳のそれの $11 \%$ よりあ高い. $\mathrm{PP}$ 全体の主要なポリペプチドは，牛乳では $\mathrm{Mr} 30 \mathrm{~K}$, $18 \mathrm{~K}, 12 \mathrm{~K}$ であるのに対して，人乳では $\mathrm{Mr} 100 \mathrm{~K}, 70$ $\mathrm{K}, 13 \mathrm{~K}$ が検出されている. 人乳の $13 \mathrm{~K}$ ポリペプチド は $\alpha$-ラクトアルブミンで, $30 \mathrm{~K}$ は温度感受性タンパ ク質, $100 \mathrm{~K}$ と $70 \mathrm{~K}$ は糖ぺプチドである ${ }^{8)}$.

なお，アメリカ酪農科学会の牛乳タンパク質の命名で は，PP は 1976 年の第 4 版 ${ }^{93)}$ までは 1 項目として設け られていた。 しかし，PPC-5 と-8は $\beta$-カゼインにお よび PPC-3 は MFGM に ${ }^{53)}$ 由来していることが明ら かになったことから，1984 年の第 5 版では ${ }^{18)}$ 継続して これらの名称を使用するとしながらも，PPC-5には $\beta$ CN-5 P, PPC-8 F には $\beta-\mathrm{CN}-4 \mathrm{P}, \mathrm{PPC}-8 \mathrm{~S}$ には $\beta$ $\mathrm{CN}-1 \mathrm{P}$ の推薦名称を設け, PP の項目は削除されてい
る， PPC-3 の詳細については後述する．また PP の総 説を参照して頂きたい ${ }^{74)}$.

\section{4. ラクトフォリンの発見}

ラクトフォリン発見の端緒は, MFGM から調製した SGP の免疫学的性質を調べるために作製した抗-SGP 血清とホエー蛋白質を二重免疫拡散法で反応したとこ ろ，1本の沈降線の出現が観察されたことである ${ }^{53)}$. し かむホエーの沈降線は SGP の主沈降線と融合し, ホエ ータンパク質で吸収した抗体ではいずれの沈降線も消失 した (Fig. 2). この一つの寒天プレート上での実験が ラクトフォリン研究の発端である.

抗-SGP 抗体と抗原的に同一であると考えられるホ エータンパク質を同定するために，まずホエータンパク 質を各種のクロマトグラフィーで分画した. Sephadex G-150 では 5 画分の内の画分 1 と 2 に, Bio Gel A-1. 5 $\mathrm{m}$ では 4 画分のうちの画分 2 に, DEAE-cellulose $(\mathrm{pH}$ 8.6) では 10 画分のうちの画分 5-10 に二重免疫拡散法, 免疫電気泳動法で抗 SGP 抗体との反応が認められた. Sephadex G-150 で得られた画分 1 と 2 の比較的分子 量の大きい画分を PAGE で分析すると, 少なくとも 2

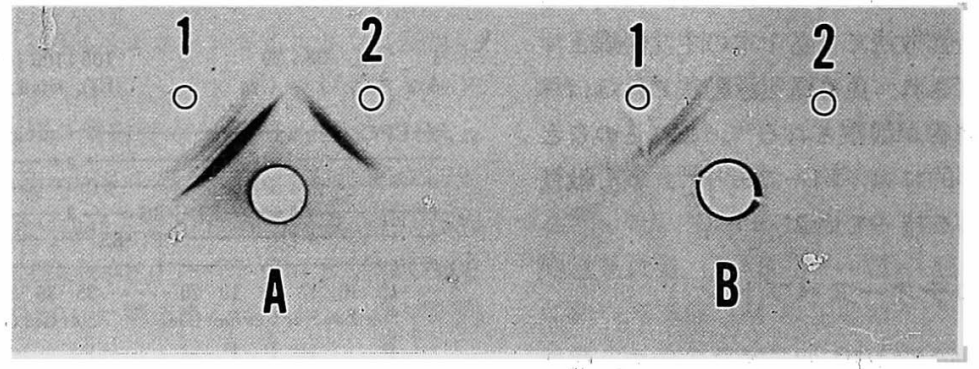

Fig. 2. Comparison of double immunodiffusion assays of whey protein (2) and the soluble glycoprotein (1) to anti-soluble glycoprotein antibody. A, Polyclonal antibody to the soluble glycoprotein. B, Polyclonal antibody to the soluble glycoprotein adsorbed with whey protein. 
牛乳のラクトフォリン: その発見，特性および機能

つのバンドが検出され，そのいずれかが抗-SGP 抗体 と反応していると考えられた．2つのタンパク質のうち の移動度の小さいバンドは免疫グロブリンに依存してい るらしいが，あう一つのバンドはこれまでに確認されて いるホエーの主要タンパク質である $\beta$-ラクトグロブリ ン， $\alpha$ ーラクトアルブミン，血清アルブミンとは関惪な いことが PAGEや免疫学的手法で示されている.

これらのことから，抗-SGP 抗体と反応する蛋白質 を加熱変性するものと耐熱性のものとに分配できるので

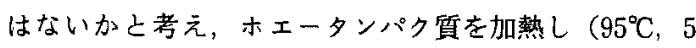
６0 分), 酸性にして, 遠心分離し, 加熱变性したタン パク質を除去した，その結果，加熱に安全な上清のタン パク質含量は $95^{\circ} \mathrm{C} 10$ 分以上の加熱で全タンパク質の 20 \%で一定に達した。これに対して，単一放射免疫拡散 法で定量される抗-SGP 抗体と反応するタンパク質 (Anti-SGP Reacting Protein) 含量は加熱前の 15\% から 20 分以上の加熱で $60 \%$ に增加し，一定に達した。

抗-SGP 抗体と反応するホエー中のタンパク質は耐熱 性のタンパク質であり，その含量は全ホエータンパク質 の 10-15\%である. 抗-SGP 抗体と反応するタンパク 質を，当初はLPでなく，Anti-SGP Reacting Protein と呼んでいた ${ }^{53)}$.

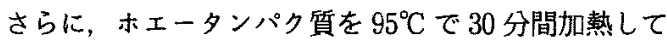
調製した耐熱生タンパク質画分の PAGE のパターンは 主に3つのバンドから成り，ホエータンパク質のそれと は異なっていたが，これまでに BRUNNER のグルー プ66,67,721 によって報告されているPP のパターンと類 似していた。

この耐熱性蛋白質を，NG ら $^{72}$ の方法に準じた硫安 塩析により，PPC-3，-5および-8の3画分に分画し， 单一放射免疫拡散法で測定された Anti-SGP Reacting Protein の含量は, PPC-3 画分に $65 \%$ 含まれて おり，全 PPの $67 \%$ が濃縮されていた ${ }^{54)}$ PPC-3 SGP の性質を比較した結果，両者のアミ八酸組成，糖 組成, PAGE での性質は異なるが, SDS-PAGE バ夕 ーンから，両者に共通な移動度をもつ少なくとも一つの 糖ペプチド（Mr17 K）の存在が見出され，両者に共通 な抗原性の存在が示唆された。 その後, PP と MFGM との免疫学的反応性は他の研究者によっても確認されて いるが, 反応成分については言及されていない63.71)

さらに，PPC-3 の他に，PPC-5や PPC-8にも AntiSGP Reacting Protein が含まれていることから,こ れらの PPC は Bio Gel A-0.5 m および DEAE-cellulose (pH 8.6) でそれぞれ分画され，これらの免没学 的関連が研究されている ${ }^{50}$. 各 PPC から得られた
Anti-SGP Reacting Protein 含む画分の抗-SGP 茫体に対する沈降線は二重免疫拡散法においていずれ あ完全に融合している，特に，DEAE-cellulose で分 画された各 PPCの Anti-SGP Reacting Protein を 含屯画分は免疫電気泳動での沈降線の移動度がいずれ あ溶出順に増大していることから，多様な形態をとる Anti-SGP Reacting Protein が各 PPC 画分に完全 に分画されずに分布しているのであって，特異な AntiSGP Reacting Protein が各 PPC に存在しているの ではない. 更に, DEAE-cellulose で分画された AntiSGP Reacting Protein に富む画分の SDS-PAGE での分析の結果は，先に示さ机た SGP と共通な Mr 17 Kのポリペプチドの他に，Mr $27 \mathrm{~K}$ の糖ペプチドが主 要であることが判明した。またAnti-SGP Reacting Protein は血液由来でないことが免疫学的に証明され ている50).

\section{5. ラクトフォリンの精製と特性}

1）プロテオースベプトンからの精製

ラクトフォリンは，PPC-3から pH 7.7 における DEAE-cellulose で LP に近接した分子量のタンパク 質を除き，次いで Sephadex G-100で LP より小さい 分子量のタンパク質を除去し,さらに Bio Gel A-15m でのゲル滵過によってLPよりあ高分子量のタンパク 質を除くことによって，単離・精製される ${ }^{40}$ ，精製され た標品はPAGEでやや幅は広いが単一のバンドであり， 抗-SGP 抗体に対する免疫電気泳動です長い1本の沈 降線を示している。また LPに相当するタンパク質の 精製は他の研究者によっても試みられている，PPC-3 を出発材料として, KESTER and BRUNNER ${ }^{53)}$ は Concanavalin A-Sepharose $て$, PAQUET and ALAIS ${ }^{75)}$ は Phenyl-Sepharose と Sephacryl S-200 で精製し ているが, PAGE で前者は LP バンドの他に高分子量 のタンパク質が, 後者ではさらに低分子量のタンパク質 の混入が観察されている。

\section{2）未加熱乳加らの精製}

末加熱乳からの LP の精製は，ホエータンパク質を 硫安塩析で分画し，2-メルカプトエタノールで還元後， Sepharose CL-6Bでのゲル滤過，pH7.6における DEAE-cellulose クロマトグラフィー，最後に HPLC を用いた Protein A-affinity クロマトグラフィーで混 入しているIgG-免疫グロブリンを除去することにより 行われている ${ }^{73}$. 得られた標品は PAGE で単一なバン ドを示すばかりでなく，抗ーウシ血清，抗-MFGM，抗- 
ホエータンパク貿抗体に対する兔疫電简泳動です 1 本の 沈降線を示した. NEJJJAR ら ${ }^{70)}$ は末加熱脱脂乳加らの ホエーを硫女塩析後，ヒドロキシアパタイトクロマトグ ラフィーで LP に相当するタンパク質の精製を試みて いる、しかし, 標品には SDS-PAGE で多数の LPよ り高分子量のタンパク質が検出されている.

\section{3）ラクトフォリンの特性}

PPC-3 から精製した LPは18\%の糖を含む糖タン パク質で ${ }^{41,63)}$ ，糖鎖よタンパク質の結合は $N$-結合之 O結合をもっている(1). アミノ酸はAsp, Thr, Ser, Glu, Leuに富み, 芳香属アミ／酸含量が少ない（Table

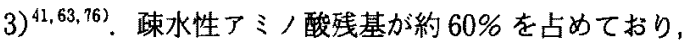
これは LP の一つの特徴である，LP は Mr $17 \mathrm{~K} \sim 67$
$\mathrm{K} の 7$ 本の杪ペプチド（I～VII）加ら構成されてい る.その内の Mr $27 \mathrm{~K}$ のVこ $17 \mathrm{~K}$ のVが主要な糖ぺ プチドであり，他の5本（I〜V) はマイナーである. KESTER and BRUNNER ${ }^{63)}$ 住要な2本の糖ペプチド (18-21 K, 25-33 K) と 3 本のマイナーなペプチド $(47$ $\mathrm{K}, 56 \mathrm{~K}, 75 \mathrm{~K})$ を報告しているが， $75 \mathrm{~K}$ のペプチト はわれわれの標品には検出されていない，またPAQUET ら ペプチドの存在を報告しているが， $27 \mathrm{~K}$ のバンドが検 出されていない.

末加熱脱脂乳から精製した LP 標品の SDS-PAGE パターンは，マイナーなポリペプチドに若干の差異は認 められるが，PAGE，焦点電気泳動，免疫学的性質， $ア ミ ノ$ 酸組成，糖組成なよ゙はPPから精製した LPの

Table 3. Amino Acid (mole $\%$ ) and Carbohydrate (weight \%) Compositions of Lactophorin (LP), Glycoprotein Corresponding to LP, Proteoseo-peptone Component-3 (PPC-3) and Soluble Glycoprotein (SGP) of Milk Fat Globule Membrane

\begin{tabular}{|c|c|c|c|c|c|}
\hline $\begin{array}{l}\text { Amino acid and } \\
\text { monosaccharide }\end{array}$ & $\begin{array}{c}\text { LP } \\
\text { Kanno }{ }^{41}\end{array}$ & $\begin{array}{l}\text { Glycoprot } \\
\text { correspondin } \\
\text { Kester } \\
\text { Brunner }\end{array}$ & $\begin{array}{l}\text { in } \\
\text { to LP } \\
\text { Paquet } \\
\text { et al. }\end{array}$ & $S G P^{5 n}$ & $\mathrm{PPC}-3^{541}$ \\
\hline Asp & 8.7 & 9.4 & 9.0 & 7.1 & 9.9 \\
\hline Thr & 9.5 & 10.6 & 8.7 & 12.3 & 7.3 \\
\hline Ser & 10.2 & 12.9 & 10.2 & 8.9 & 9.6 \\
\hline Glu & 16.0 & 15.3 & 14.6 & 13.2 & 19.3 \\
\hline Pro & 2.7 & 5.2 & 4.9 & 3.8 & 6.8 \\
\hline Gly & 3.3 & 3.2 & 3.9 & 4.6 & 2.7 \\
\hline Ala & 4.7 & 4.7 & 4.8 & 5.0 & 4.6 \\
\hline Cys $(1 / 2)$ & 0.3 & 0.6 & 1.4 & 0.5 & tr \\
\hline $\mathrm{Val}$ & 3.7 & 4.4 & 3.3 & 3.7 & 4.2 \\
\hline Met & 2.3 & 1.8 & 3.4 & 3.0 & 1.3 \\
\hline Ile & 6.4 & 6.4 & 5.6 & 3.9 & 6.7 \\
\hline Leu & 11.7 & 11.3 & 10.3 & 12.0 & 9.5 \\
\hline Tyr & 1.5 & 1.1 & $\operatorname{tr}$ & 1.5 & 1.3 \\
\hline Phe & 2.7 & 2.4 & 3.2 & 2.7 & 2.5 \\
\hline Lys & 8.8 & 5.6 & 8.6 & 9.9 & 7.7 \\
\hline $\mathrm{His}$ & 4.9 & 2.4 & 3.8 & 4.4 & 2.9 \\
\hline Arg & 4.1 & 2.5 & 4.0 & 2.6 & 3.9 \\
\hline $\operatorname{Trp}$ & nd & 0.3 & nd & 0.4 & nd \\
\hline HyP\# & 58.4 & 56.6 & 58.2 & 60.9 & 55.8 \\
\hline PCG\#\# & 42.5 & 35.2 & 40.0 & 37.2 & 43.7 \\
\hline Fucose & 0.3 & 0.8 & nd & 0.8 & 0.4 \\
\hline Mannose & 2.2 & $6.8^{*}$ & nd & $13.9^{*}$ & $4.2^{*}$ \\
\hline Galactose & 34 & & & & \\
\hline GalNAc & 2.2 & $7.1^{* *}$ & nd & $8.1^{* *}$ & $1.7^{*}$ \\
\hline GlcNAc & 3.9 & & & & \\
\hline Sialic acid & 6.5 & 4.0 & nd & 8,0 & 2.7 \\
\hline Total & 18.5 & 18.7 & - & 30.8 & 8.9 \\
\hline
\end{tabular}

nd, Not determined; tr, trace in amount. \#, Hydrophobic amino acids including Thr, Pro, Ala, Cys, Val, Met, Ile, Leu, Tyr, Phe, Lys, and Arg. \#, Polar amino acids with charged group (Asp, Glu, Lys, His, and $\mathrm{Arg})$. *and ${ }^{* *}$, determined as hexoses and hexosamines, respectively. 
牛乳のラクトフォリン: その発見，特性および機能
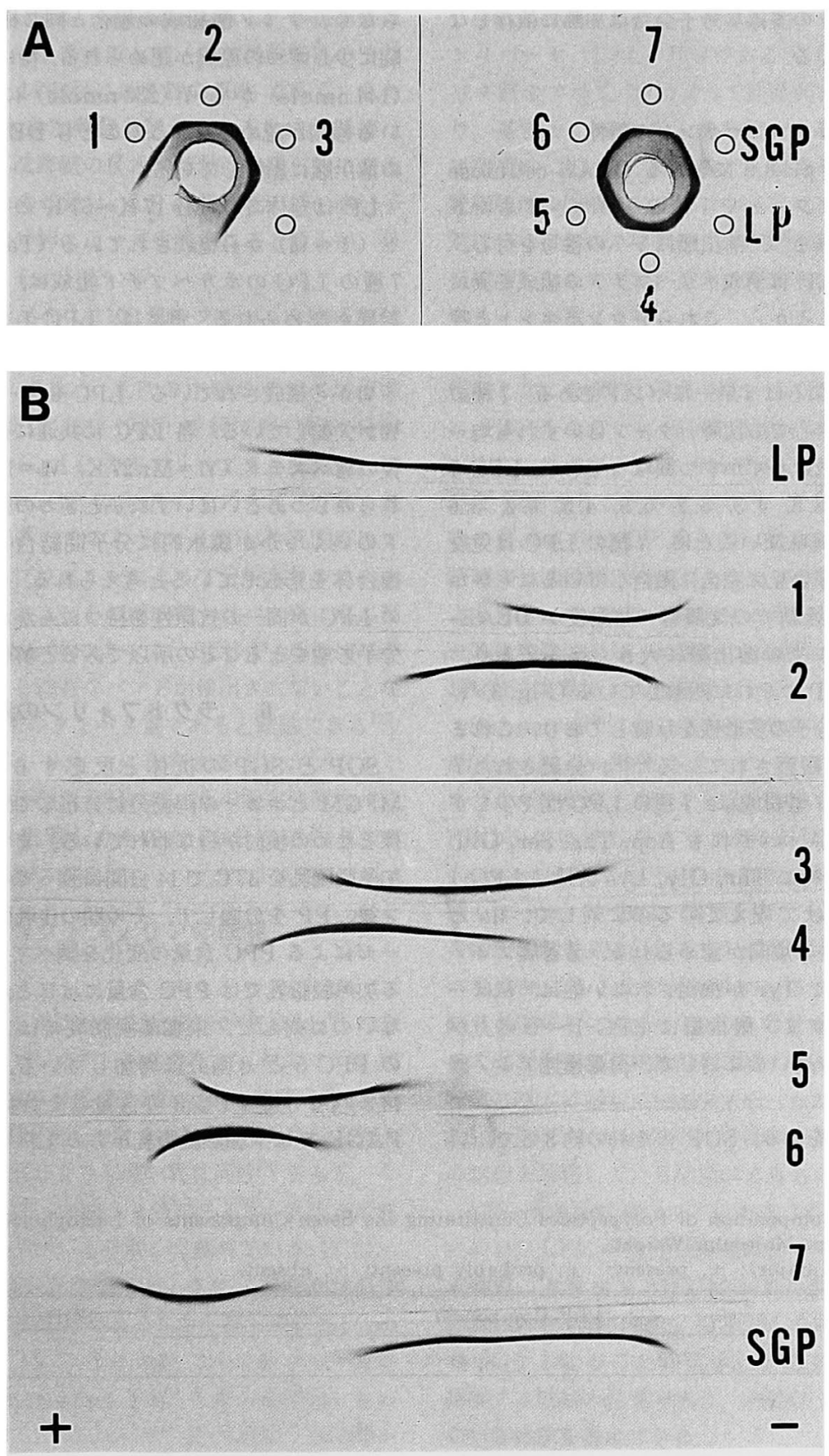

Fig. 3. Double immunodiffusion (A) immunoelectrophoretic (B) patterns of seven components (1-7) of lactophorin (LP). Troughs contains anti-SGP antibody. SGP, soluble glycoprotein isolated from bovine milk fat globule membrane. 
それらと非常に良く類似していだ3)。これらのことは， LP の存在およびその多様な分子会合は加熱に依存しな いことを証明している。

\section{4）ラクトフォリンコンポネントの特性}

精製した LP は pH 8.6 における DEAE-cellulose でのクロマトグラフィーで7種の LP コンポネント （LPC）に分離される ${ }^{40)}$. 溶出順に 1-7 の番号を付し， 後述するように，LPは構成ポリペブチドの組成を異に する会合体であることから，これらをコンポネントと呼 称することにした，价離された７画分はPAGEでわず 加ずつ移動度の異なるほぼ単一なバンドである，7種の LPC は分析用超遠心での沈降パターンはいずれす均一 であるが，沈降係数はわずかずつ異なっており，LPC-1 〜-7ではそれぞれ $3.8 ， 4.8 ， 5.2 ， 5.5 ， 4.5 ， 5.2 ， 5.6$ $\mathrm{S}$ である ${ }^{41}$. 更に興味深いことに，7 種の LPC は免疫 二重应散での沈降線は互に完全に融合しているにすかか わらず，免疫電気泳動での沈降線の移動度が DEAEcellulose (pH 8.6) での溶出順に大きくなっており, 全体の長さは精製LPのそれに匹敵している（Fig. 3) ${ }^{40}$. これはこの蛋白質分子の多形性を示唆しており，これま でむ粗 LP 試料で観察されている ${ }^{50,54)}$. 分離された 7 種の LPC のアミノ酸組成は， 7 種の LPC 間で少しず つ異なっているが，いずれも Asp, Thr, Ser, Glu, Leu, Lys が多く，特に Thr, Gly, Lys 含量は LPC-1 加 LPC-7に加けて增えているのに対して, lle と Arg は減少している傾向が認められる。芳香属アミノ 酸含量は LPC-1 で Tyr が検出されない他は，ほぼ一 定である. 疎水性アミ/酸含量は LPC-1〜 -30方が LPC-5 -6 よりも高いのに対して, 荷電極性了ミノ酸 含量は逆である。

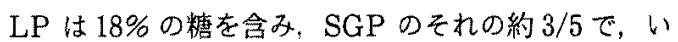

ずれもFuc, Man, Gal, GalNAc, GlcNAc, SA か らなり，アミ／酸組成の場合と同じ様に，7種の LPC 間に少しずっの差異が認められる. 特に, SA は LPC-1 (144 nmole) 加ら-7 (232 nmole) に加けて增加して いる傾向が認められ，このことも DEAE-cellulose で の溶出順に影響している.

LP は全体では Mr $17 \mathrm{~K} \sim 67 \mathrm{~K}$ の 7 本のポリペプチ ド（I～VII）加ら構成されている (Table 4). しかし， 7 種の LPC のポリペプチド組成は，LPC 間で著しい 差異が認められる，例えば，LPC-1 はポリペプチドVII のみで，-2 はVレVVI， -3 はV，VI，VII，そして-6は I 〜Vから楧成されている，LPC-6 と-7では糖ぺプチド VIIが欠如している．各 LPC に共通に存在する主要な 2 種の糖ぺプチド（VI $=\mathrm{Mr} 27 \mathrm{~K}, \mathrm{VII}=17 \mathrm{~K} ）$ のうち，こ れらの 2 つあるいはいずれかと5つの徵量のポリペプチ トのいくつかか柾水的に分子間結合して多形性の LP 複合体を形成していると考えられる。このことが，7種 の LPC 汃同一の抗原性を持つにもかかわらず，多様な 分子形態をとることの所以であると解釈される。

\section{6. ラクトフォリンの起源}

SGP と SGP の抗体と反応するLPがそれぞれ MFGM とホェーの両画分に分布していることの起因を 探るための検討が行なわれている. まず加熱脱脂乳と末 加熱脱脂乳を $37^{\circ} \mathrm{C}$ で 14 日間に渡ってインキュベーショ ン後，PP を分画して，その間の牛乳固有のプロティナ 一ゼによる PPC 含量の变化を調べている ${ }^{48)}$. 対照であ る加熱脱脂乳では PPC 合量にはほとんど変化が見られ ないのに対して，未加熱脱脂乳では， $\beta$-カゼイン由来 の PPC-5 と-8 画分は増加している。しかし，LP が 含まれている $\mathrm{PPC}-3$ の含量はそれほど増加しない． PAGE では夫加熱脱脂乳からの LP のバンドは6 日目

Table 4. Composition of Polypeptides Constituting the Seven Components of Lactophorin (LP) and Their Apparent Molecular Weight

$H$, presence (major); + , present; \pm , probably present; - , absent.

\begin{tabular}{|c|c|c|c|c|c|c|c|c|c|c|}
\hline \multirow{2}{*}{\multicolumn{2}{|c|}{$\begin{array}{l}\text { Poly- } \\
\text { peptide }\end{array}$}} & \multicolumn{7}{|c|}{ LP Component } & \multirow[t]{2}{*}{ SGP } & \multirow{2}{*}{$\begin{array}{l}\text { Molecular } \\
\text { weights }\end{array}$} \\
\hline & & 1 & 2 & 3 & 4 & 5 & 6 & 7 & & \\
\hline 1 & (GP) & - & - & - & - & + & + & + & + & 67,000 \\
\hline II & (GP) & - & - & - & - & \pm & + & + & - & 63,000 \\
\hline III & & - & - & - & + & + & + & \pm & - & 58,000 \\
\hline IV & & - & - & - & + & + & + & + & - & 50,000 \\
\hline $\mathrm{V}$ & & - & - & + & + & + & \pm & \pm & - & 42,000 \\
\hline *VI & $(\mathrm{GP})$ & - & $H$ & $H$ & H & H & $H$ & $\bar{H}$ & + & 27,000 \\
\hline$*$ VII & (GP) & H & H & $H$ & H & + & - & - & + & 17,000 \\
\hline
\end{tabular}

GP, Glycoprotein positive to carbohydrate stain; *, Major glycopeptide; SGP, Soluble glycoprotein. 
には消失している，そこで LP の変動を単一放射免疫 拡散法で定量した結果，加熱脱脂乳のLP の抗原性は 完全に保持されているのに対して，末加熱脱脂乳のそれ は次第に隇少し，14日目には 0 日の $20 \%$ である。また 免疫電気泳動でも未加熱脱脂乳からの LP の沈降線は 消失はしないが，沈降線の長さや移動度は経日的に变化 している.これらの結果は，LP は脱脂乳の他の高分子 タンパク質の蛋白分解によって生成されるどころか，分 解されていることを示している.

さらに, LP 標品を $1 / 1100$ 量のプラスミンあるいは 1/1000量のトリプシンによっで温和な条件化でインキ ニベート $\left(37^{\circ} \mathrm{C}\right)$ すると，LP の主要なポリペプチド $(\mathrm{Mr} 27 \mathrm{~K})$ は中間体 $(\mathrm{Mr} 17 \mathrm{~K})$ を経て経日的に分解 されていることから，LP の主ボリペプチド（27K）の 限定加水分解物が SGP の主ポリペプチド（17 K）で あると示唆される ${ }^{49}$ 。このように，LPは牛乳固有のプ ロテアーゼであるプラスミンによって分解されやすい．

また, MFGM およびその構成糖タンパク質に富んだ 画分のプラスミン分解によって，SDS-PAGEでLP の移動度に相当する顕著な゙゙ンドが検出されないことな ビから，LP は生来のタンパク質であると結論できる゙7. 以上の結果から，ホエーに存在する LP がプラスミ ンによって限定的に加水分解され，その限定分解物 (17 K）が MFGM に吸着したものが SGP の主要ポリペ プチドであると推測される.

\section{7. ラクトフォリンの機能}

1) 乳化機能

PP とその分画した画分の乳化機能が $\mathrm{KANNO}^{42}$ の方 法により比較されている ${ }^{88}$. 同条件下で (タンパク質 40 $\mathrm{mg} / 1 \mathrm{~g}$ 乳脂肪, 擋拌速度 $19,500 \mathrm{rpm}$, 擋拌時間 2 分, 乳化温度 $45^{\circ} \mathrm{C}, \mathrm{pH} 7.0$, 全量 $5 \mathrm{ml}$ )，LP を含む PPC3 画分はいずれの画分より屯高い乳化活性 ${ }^{79}$ をむち，こ

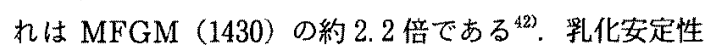
屯他の画分（0.4〜0.5）上り著しく優れている(1.0). この LP 画分の高い乳化能力は，LPに富む画分を含 むエマルションの脂施球のサイズが中間平均直径 $2 \mu \mathrm{m}$ で, いずれの画分 $(5.5 \sim 8.0 \mu \mathrm{m})$ よりあ小さく，しか 6 $1 \mathrm{~cm}^{3}$ 当りの比表面積は $\mathrm{PPC}-3$ 画分を添加したエ マルションでは $31,000 \mathrm{~cm}^{2}$ で, 他の画分 $(10,000 \sim$ $12,000 \mathrm{~cm}^{2}$ ) の約 3 倍であることからあ裹付けられる.

SHIMIZU ら ${ }^{87)}$ はPPのうち, LP の主要ポリペプチド が脂肪球表面に特異的に吸着することを報告している. PPC-3 画分の主要成分は LP であり，LP のもつ高い 疎水性率が乳化に寄与していると考元られる。
2）リポリシスの抑制作用

牛乳に存在するリパーゼは人乳之共通のリポプロティ ンリパーゼ (LPL) だけである ${ }^{15)}$ LPLは、リポタン パク質のアポ C Iによって活性化されるのが特徴であ り，基質としての TGを分解できるが，乳脂肪球のコ ア脂質の TG を分解することができない，末処理の， 乳脂肪球の破壊されていない牛乳では，リポリシスは全 然起こらないが，牛乳を2 分間超音波処理して乳脂肪球 を破壊したものでは，直ちに内因性の LPLによってリ ポリシスが生じる6,7.

牛乳を超音波により破壊すると,リポリシスは時間の 経過と共に直線的に進行する。この超音波処理した牛乳 に PPC-3 あるいは LP を添加すると $(40 \mathrm{mg} / \mathrm{ml}$ of milk)，リポリシスをそれぞれ 90 分後で $43 \%$ お上び $67 \%$ 抑制することが出来る ${ }^{58}$. リリポリシスを抑制する のに要求されたLP 量が高いのは超音波好理により脂 肪球の比表面積加增大したことに起因している．LPに ょる LPL やリバーゼに対する阻害作用は，LP の優れ た乳化機能により，基質である脂肪球を被翼・修復する 高い能力に依るあのと推定される。

SHIMIZU ら ${ }^{84)}$ は, MFGM や SGP が膵りパーゼや Rhizopus delemer 由来のリパーゼによる乳脂肪のリ ポリシスを抑制することを認めている，ANDERSON ${ }^{13}$ は PPC-3が牛乳のリポリシスを抑制することを，また CARTIER ら ${ }^{11,12)}$ はPPC-3 およびそれから部分的に精 製したタンバク質は，基質として intralipid と牛乳か ら精製した LPLに対して，濃度の增加と共にリポリシ スを抑制することを報告している。このリポリシスを $50 \%$ 抑制するに必要な PPC-3の量は $0.4 \mathrm{mg}$ である この抑制作用は，抑制剂の濃度とともに高くなるが，基 質量の增大に対しては減少する.したがって, MFGM, SGP, PPC-3 および LP の抑制効果は LPL の基質へ の結合を阻害している結果によるものと考えられる。

LPL が乳脂肪球のコアにある TG を加水分解できな いのは，LPL が乳脂肪球に結合することを防止してい る物質，すなわち MFGM が乳脂肪球を被覆している 物理的防御機構の他に，MFGM の構成タンパク質であ るSGP およびこれの抗体と反応する LP が脂肪球を 修復する効果の結果であり，牛乳はLPL に対する二重 の防御機構を備えている。

\section{8. ま と め}

Fig. 4 に LP と SGP との関連を仮説的に図示して ある、まずホエーには LP の基本構造である $27 \mathrm{~K}$ と 幾つかのマイナーなボリペプチドから構成されている 


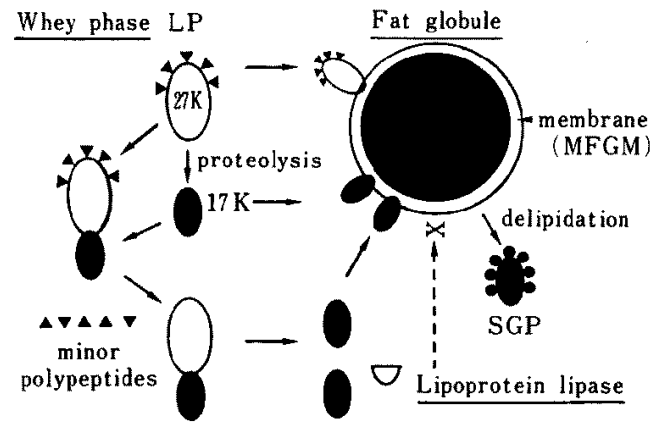

Fig. 4. Relationship between lactophorin (LP) in whey and the soluble glycoprotein (SGP) in milk fat globule membrane (MFGM).

LPC-5，-6，-7が存在する。これらがプラスミンによ り加水分解されると, $17 \mathrm{~K}$ ポリペプチド，すなわち， LPC-1 に相当するものが生成され，これと $27 \mathrm{~K} の$ LP が結合して，LPC-2，-3，-4 構成するようにな る。この $17 \mathrm{~K}$ ボリペブチドは $27 \mathrm{~K}$ ポリペプチドを中 心に構成されている LPよりも脂肪球皮膜に吸着され やすい性質を持ち，MFGM を修復することができる。 その結果として，LP あるいは SGP は LPL に対する 抑制作用をもつようになる，他方，MFGM に吸着した $17 \mathrm{~K}$ ポリペプチドは, 脱脂されたりすると，LP の構 成ポリペプチドとは異なる徽量のポリペプチドを結合し $\tau$ MFGM から離脱し, 可溶性の SGP となる.

以上，ホエー中の抗-SGP 抗体上反応する蛋白質を LP と命名し，このLP を精製し，更に 7 成分にまて 分離し，それらの理化学的特性を明らかにし，LP 上他 の乳蛋白質のプラスミン分解との関連の研究を行ない， かつ LP の機能の一端について要約した。 まだ LPの 主要ポリペプチドの一次構造, 糖鎖構造, LP の限定加 水分解物とSGP の主要ポリペプチドとの関連, 乳腺で の生合成などの研究が残されている、またLPは比較 的小分子で，高い蹯水性を持っていることから多くの機 能が期待され，その開発が待たれる.

\section{謝辞}

御董陶頂きました東京大学名誉教授津郷友吉先生，本 研究の端緒を拓いていただき，多大な御指導・御鞭撻を 賜わりました東京大学名誉教授山内邦男先生, 並びに宇 都宮大学名誉教授大武由之先生, SGP の共同研究者で あった現静岡県立大学助教授清水 誠先生に深甚の謝意 を表します，また，御協力頂いた東京大学農学部および 宇都宮大学䀼学部の畜産物利用学研究室の皆さんに心か
ら御礼中し上げます。多くの儀牲を払ってくれている妻 と二人の子供に感謝する。

\section{文献}

1) Anderson, M., Inhibition of lipolysis in bovine milk by proteose-peptone. J. Dairy Res., 48:247-252. 1981.

2) ANDREWS, A.T., The composition, structure and origin of proteose-peptone component 5 of bovine milk. Eur. J. Biochem., $90: 59-65.1973$.

3) ANDREWS, A.T., The composition, structure and origin of proteose-peptone component $8 \mathrm{~F}$ of bovine milk. Eur. J. Biochem., 90 : 67-71. 1978.

4) Aschaffenburg, R. and J. Drewary, New procedure for the routine determination of the various non-casein proteins of milk. Int. Dairy Congr. 15th, London, 3 : 1631-1637. 1959.

5) BargmanN, W. and A. KNOOP, On the morphology of milk secretion. Light and electron microscopic studies on the mammary gland of the rat. 2. Zellforsch. Mikrosk. Anat., 49 : 344-388. 1959.

6) Bengtsson, G. and T. Olivecrona, Lipoprotein lipase: Some effects of activator proteins. Eur. J. Biochem., 106 : 549-555. 1980.

7) Bengtsson, G. and T. Olivecrona, Activation of lipoprotein lipase by apolipoprotein C II. Demonstration of an effect of the activator on the binding of the enzyme to milk-fat globules. FEBS Lett., $147: 183-$ 187. 1982.

8) Bezkorovainy, A., J.H. Nichols and D.A. Sly, Proteose-peptone fractions of human and bovine milk. Int. J. Biochem., $7: 639-645.1976$.

9) Bruder, G., H. Heid, E.-D. Jarasch, T.W. KeEnan and I.H. MATHER, Characteristics of membranebound and soluble forms of xanthine oxidase from milk and endotherial cells of capillaries. Biochim. Biophys. Acta, 701 : 357-369. 1982.

10) Brunner, J.R. and M.P. Thompson, Characteristics of several minor-protein fractions isolated from bovine milk. J. Dairy Sci., 44 : 1224-1237. 1961.

11) Cartier, P. and Y. Chilliard, Effects of different skim milk fraction on activity of cow milk purified lipoprotein lipese. J. Dairy Sci., 69 : 951-955. 1986.

12) Cartier, P., Y. Chilliard and D. Paquet, Inhibiting and activating effects of skim milks and proteosepeptone fraction on spontaneous lipolysis and purified lipoprotein lipase activity in bovine milk. J. Dairy Sci., $73: 1173-1177.1990$.

13) COULSON, E.J. and R.H. JACKsON, The mucoprotein of the fat/plasma interface of cow's milk. II. Immunochemical characterization. Arch. Biochem. Biophys., $97: 378-382.1962$.

14) Deeney, J.T., H.M. Valivullak, C.H. Dapper, D.P. DYLeWsKI and T.W. KEENAN, Microplipid droplets in milk secreting mammary epitherial cells: Evidence that they originate from endoplasmic reticulum and are precursors of milk lipid globules. Eur. 


\section{牛乳のラクトフォリン: 甹の発見，特性および機能}

J. Cell Biol., $38:$ 16-26. 1985.

15) Deeth, H.C. and C.H. Fitz-Gerald, Lipolytic enzymes and hydrolytic rancidity in milk and milk products. Development of Dairy Chemistry, Vol. 2. (Fox, P.F. ed.) 195-239. Applied Science Publishers. London. 1983.

16) Drlewski, D.P., C.H. Dapper, H.M. Valivullah, J.T. Deeney and T.W. Keenan, Morphological and biochemical characterization of possible intracellular precursors of milk lipid globules. Eur. J. Cell Biol., 35 : 99-111. 1984.

17) Eigel, W.N., Identification of proteose-peptone component 5 as a plasmin-derived fragment of bovine $\beta$-casein. Int. J. Biochem., 13 : 1081-1086. 1981.

18) Eigel, W.N., J.E. Butler, C.A. Ernstrom, H.M. Farrell, Jr., V.R. Halwalkar, R. Jenness and R.M. WHITNEY, Nomenclature of proteins of cow's milk: Fifth revision. J. Dairy Sci., 67: 1599-1631. 1984.

19) Eigel, W.N., C.J. Hofmann, B.A.K. Chibber, J.M. Tomich,, T.W. KeEnan and E.T. Mertz, Plasminmediated proteolysis of casein in bovine milk. Proc. Natl. Acad. Sci, 76 : 2244-2248. 1979.

20) EIGEL, W.N. and T.W. KEENAN, Identification of proteose-peptone component 8 slow as a plasminderived fragment of bovine $\beta$-casein. Int. J. Biochem., $10: 529-535.1979$.

21) Franke, W.W., H.W. Heide, C. Grund, S. Winter, C. Freudenstein, E. Schmid, E.-D. Jarasch and T.W. KeEnan, Antibodies to the major insoluble milk fat globule membrane-associated protein: Specific location in apical regions of lactating epithelial cells. J. Cell Biol., 89 : 485-494. 1981.

22) Freudenstein, C., T.W. Keenan, W.N. Eigel, M. Sasaki, J. Stadler and W.W. Franke, Preparation and characterization of the inner coat material associated with fat globule membranes from bovine and human milk. Exp. Cell Res., 118 : 277-294. 1979.

23) Ganguli, N.C., B.S. Gupta, O.N. Agafwala and V.R. BHALERAO, The proteose-peptone fraction of milk: Isolation and properties of proteose-peptone and proteose from cow and buffalo. Indian $\mathrm{J}$. Biochem., 2 : 189-192. 1965.

24) Gordon, W.G., M.L. Groves, R. Greenberg, S.B. Jones, E.B. Kalan, R.F. Peterson and R.E. TOWNEND, Probable identification of $\gamma_{-}$, TS-, R- and S-caseins as fragments of $\beta$-casein. J. Dairy Sei., 55 : 261-263. 1972.

25) Greenwalt, D.E. and I.H. Mather, Characterization of an apically derived epithelial membrane glycoprotein from bovine milk, which is expressed in capillary endothelia in diverse tissues. J. Cell. Biol., 100 : 397-408. 1985.

26) Groschlaude, F., M.-F. Mache, J.-C. Mercter and B. Ribadeau-Dumas, Primary structure of $\alpha_{\mathbf{s} 1}$ casein and $\beta$-casein of bovine milk. Correction. Eur. J. Biochem., $40: 323-324$. 1973. (French)

27) Groves, M.L., W.G. Gordon, E.B. Kalan and S.B.
Jones, Composition of bovine $\gamma$-caseins $A^{1}$ and $A^{3}$ and further evidence for a relationship in biosynthesis of $\gamma$-and $\beta$-caseins. J. Dairy Sci., 55: 1041-1049. 1972.

28) Groves, M.L., W.G. Gordon, E.B. Kalan and S.B. JONES, TS- $A^{2}$, TS-, B, R- and S-caseins: Their isolation, composition and relationship to $\beta_{-}$and $\gamma$-casein polymorphs $A^{2}$ and B. J. Dairy Sci., $56: 558-$ 568. 1973.

29) Heide, H.W., S. WinteR, G. Bruder, T.W. KeEnan and E.-D. JARASCH, Butyrophilin, an apical plasma membrane-associated glycoprotein characteristic of lactating mammary glands of diverse species. Biochim. Biophys. Acta, 728: 228-238. 1983.

30) Huggins, J.W. and K.L. Carraway, Purification of plasma membranes from rat mammary gland by a density perturbation procedure. J. Supramol. Struct., $5: 59-63.1976$.

31) Huggins, J.W., T.P. Trenbeath, R.W. Chesnut, C.A.C. Carraway, and K.L. Carraway, Purification of plasma membranes from rat mammary gland: Composition of subfractions with rat milk fat globule membrane. Exp. Cell Res., 126 ; 279-288. 1980.

32) Imam,A., D.J.R. Laurence and A.M. Neville, Isolation and characterization of a major glycoprotein from milk-fat-globule membrane of human breast milk. Biochem. J., $193:$ 47-54. 1981.

33) Imam, A., D.J.R, Laurence and A.M. Neville, Isolation and characterization of two individual glycoprotein components from human milk-fat-globule membranes. Biochem. J., $207: 37-41.1982$.

34) JACKSON, R.H. E.J. COULSON and W.R. CLARK, The mucoprotein of the fat/plasma interface of cow's milk. I. Chemical and physical characterization. Arch. Biochem. Biophys., $97: 373-377.1962$.

35) Jarasch, E.-D., C. Grund, G. Bruder, H.W. Heid and T.W. KEENAN, Localization of xanthine oxidase in mammary gland epithelium and capillary endothelium. Cell, $25: 67-82.1981$.

36) JENnESS, R., Characterization of milk serum protein component 5. J. Dairy Sci., 42: 895. 1959. (Abstract)

37) Johnson, V.G. and I.H. Mather, Monoclonal antibodies prepared against PAS-I, butyrophilin and GP-55 from guinea-pig milk-fat-globule membrane bind specifically to the apical pole of secretory-epithelial cells in lactating mammary tissue. Exp. Cell Res., 156 : 144-158. 1985.

38) KaMINOGAWA, S., H. MizobuchI and K. YamauCHI, Comparison of bovine milk protease with plasmin. Agric. Biol. Chem., 36 : 2163-2167. 1972.

39) KanNo, C., Receptor proteins for Concanavalin A and wheat germ agglutinin of bovine milk fat globule membrane probed by affinity chromatography in the presence of sodium dodecyl sulfate. Agric. Biol. Chem., 50 : 2997-3003. 1986.

40) KanNo, C., Purification and separation of multiple forms of lactophorin from bovine milk whey and their immunological and electrophoretic properties. J. Dairy 
Sci., $72: 883891.1989$.

41) Kanno, C., Characterization of multiple forms of lactophorin isolated from bovine milk whey. J. Dairy Sci., 72 : 1732-1739, 1989.

42) KaNNo, C., Emulsifying properties of bovine milk fat globule membrane in milk fat emulsion: Conditions for the reconstitution of milk fat globules. J. Food. Sci., 54 : 1534-1539. 1989.

43) Kanno, C., Secretory membranes in the lactating mammary gland. Protoplasma, 154 : in press. 1990.

44) KanNo, C., H. HatToRI and K. Y AMAUChl, Isolation and characterization of plasma membrane from lactating bovine mammary gland. Biochim. Biophys. Acta, 689 : 121-134. 1982.

45) KanNo, C., H. Hattorl and K. Yamauchi, Characterization of plasma membrane proteins from lactating bovine mammary gland. Agric. Biol. Chem., 51 : 1325-1332, 1987.

46) Kanno, C., H. Hattori and K. Yamauchi, Lipid composition of plasma membranes isolated from lactating bovine mammary gland. Agric. Biol. Chem., 51 : 2995-3001. 1987

47) Kanno, C and D.-H. KIM, A simple procedure for the preparation of bovine milk fat globule membrane and a comparison of its composition, enzymatic activities and electrophoretic properties with those prepared by other methods. Agric. Biol. Chem., 54: 2845-2854. 1990.

48) Kanno, C. and H. OGAWA, Proteolysis of lactophorin in skim milk by bovine milk indigenous proteases. Jpn. J. Zootech. Sci., 60 : 797-806. 1989.

49) Kanno, C. and H. Ogawa, Proteolytic degradation of lactophorin from bovine milk by plasmin and trypsin. Jpn. J. Zootech. Sci., 60 : 865-873, 1989.

50) KanNo, $\mathrm{C}$ and Y. OHTAKE, Immunological and electrophoretic characteristics of anti-SGP reacting protein among component $-3,-5$ and -8 fractions of proteose-peptone of bovine milk: Evidence for the multiple forms. Jpn. J. Zootech. Sci., 52: 282-296. 1981.

51) KANNo, C., M. ShimizU and K. YAMAUCHi, Isolation and physico-chemical properties of a soluble glycoprotein fraction of milk fat globule membrane. Agric. Biol. Chem., 39 : 1835-1842. 1975.

52) Kanno, C., M. Shimizu and K. Yamauchi, Polydispersity and heterogeneity of the soluble glycoprotein isolated from bovine milk fat globule membrane. Agric. Biol. Chem., $41: 83-87.1977$.

53) Kanno, C. and K. Yamauchi, Atigenic identity between the soluble glycoprotein of milk fat globule membrane and a heat-stable protein fraction of whey. Agric. Biol. Chem., 42 : 1697-1705. 1978.

54) KanNo, C. and K. YaMAUCHI, Relationship of soluble glycoprotein of milk fat globule membrane to component-3, -5 and -8 fractions of proteose-peptone. Agric. Biol. Chem., 43:2105-2113. 1979.

55）菅野長右土門，牛乳脂肪球皮膜に関寸る最近の研究一特に 棈成蛋白質を中心に一。傗会報，51：75-88．1980.

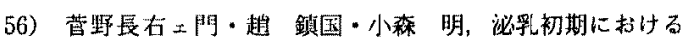
牛乳でのワシ乳腺細胞の細胞膜標織醉萃の活性の変動と 分泝，第 80 回日本畜産学会大会講演要旨，pp. 61. 1988.

57）管野長右土門・岩本 泉,ラクトフォリンは乳脂肪球皮膜

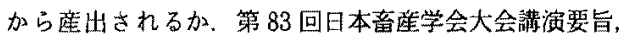
pp. 177. 1990.

58）菅野長石土門・土井隆司，未発表

59) KeEnan, T.W., D.P. DYLEWSK1, T.A. WOOdFoRd and R. H. ForD, Origin of milk fat globules and the nature of the milk fat globule membrane. Developments in Dairy Chemistry, vol. 2, (Fox, P.F. ed.) 83-118. Applied Scientific Publishers. London. 1983.

60) Kegnan, T.W., K.M. Powell, M. Sasaki, W.N. EIGEL and W.W. FRANKE, Membranes of mammary gland. XIV. Isolation and partial characterization of a high molecular weight glycoprotein fraction from bovine milk fat globule membrane. Cytobiologic, 15 : 96-115. 1977.

61) Keenan, T.W., I.H. MAther and D.P. DyLEWSKI, Physical equilibra: Lipid phase. Fundamentals of Dairy Chemistry, Third ed. (WoNG, N.P. ed.) 511-582, Van Nostrand Reinhold. New York. 1988.

62) KeEnan, T.W., H.M. Valivullah and J.T. DUNLEVY, Isolation of plasma membranes from mammary gland by two-phase polymer partioning. Anal. Biochem., 177 : 194-198. 1989.

63) KeSter, J.J. and J.R. Brunner, Milk fat-globule membrane as possible origin of proteose-peptone glycoprotein. J. Dairy Sci., 65 : 2241-2252. 1982.

64) KITCHEN, B.J., A comparison of the properties of membranes isolated from bovine skim milk and cream. Biochim. Biophys. Acta. $356:$ 257-269. 1974.

65) KOLAR, C.W. and J.R. BRUnNer, Characteristics of proteose-peptone component five and eight. J. Dairy Sci., $51: 945$. 1968. (Abstr.)

66) Kolar, C.W. and J.R. Brunner, Proteose-peptone fraction of bovine milk: Distribution in the protein system. J. Dairy Sci., 52 : 1541-1546. 1969.

67) Kolak, C.W. and J.R. Brunner, Proteose-peptone fraction of bovine milk: Lacteal serum component 5 and 8-Casein associated glycoproteins. J. Dairy Sci., 53 : 997-1008. 1970.

68) LARSON, B.L. and G.D. RoLleri, Heat denaturation of the specific serum proteins in milk. J. Dairy Sci., $38: 351-360.1955$.

69) McPherson, A.V and B.J. KItChen, Reviews of the progress of diary science: The bovine milk fat globule membrane-its formation, structure and behaviour in milk and dairy products. J. Dairy Res., 50 : 107-133. 1983.

70) Nejuar, Y., D. Paquet, F. Aubert and G. Linden, The PP 3 component of the proteose-peptone. Extrac tion from unheated skim milk. Milchwissenschaft, 45 : 84-87. 1990.

71) Nejuar, Y., D. Paquet, G. Godbillon and Y.L. DEAUT, Immunological relationship between the hydrophobic fraction of proteose-peptone and the milk fat globule membrane of bovine milk. Int. J. 
Biochem., 18 : 893-900. 1986.

72) Na, W.S., J.R. Brunner and K.C. RheE, Proteosepeptone fraction of bovine milk: Lacteal serum component 3-A whey glycoprotein. J. Dairy Sci., 53 : 987-996. 1970.

73）小川英子・营野長右ェ門，未加熱牛乳加らのラトフォ リンの単離とその特性. 日本宸芸化学会 1989 年大会. 63 : 570.1989.

74) PaQUeT, D., Review: The proteose-peptone fraction of milk. Lait, 69 : 1-21. 1989. (French)

75) Paquet, D. and C. Alais, Purification and some molecular characteristics of the "component- 3 " of proteose-peptone. Lait, $62: 338-349.1982$. (French)

76) PAqueT, D., Y. NejJaR and G. Linden, Study of a hydrophobic protein fraction isolated from milk proteose-peptone. J. Dairy Sci., 71 : 1464-1471. 1988.

77) Patton, S. and T.W. KeEnan, The relationship of milk phospholipids to membranes of the secretory cell. Lipids, 6 : 58-61. 1971.

78) Patton, S. and T.W. KeEnan, The milk fat globule membrane. Biochim. Biophys. Acta, 415 : 273-309. 1975.

79) Pearce, K.N. and J.E. Kinsella, Emulsifying properties of proteins: Evaluation of a turbidmetric technique. J. Agric. Food Chem. 26 : 716-723. 1978.

80) Ribadeau-Dumas, B., G. Brignon, F. Grosclaude and J.-C. MERcIER, Primary structure of $\beta$-casein of bovine milk. Complete sequence. Eur. J. Biochem., 25 : 505-514. 1972. (French)

81) Rose, D., J.R. BRunNer, E.B. Kalan, B.L. Larson, P. MELNYCHYN, H.E. SWAISGOOD and D.F. WAUGH, Nomenclature of the proteins of cow's milk. Third revision. J. Dairy Sci., 53 : 1-17. 1970.

82) RowLAND, S.J., The soluble protein fraction of milk. J. Dairy Res., 8 : 6-14. 1937.

83) Shimizu, M., C. Kanno and K. Yamauchi, Dissociation of the soluble glycoprotein of bovine milk fat globule membrane by sodium dodecyl sulfate. Agric. Biol. Chem., 40 : 1711-1716. 1976.

84) Shimizu, M., H. MiYaji and K. Yamauchi, Inhibition of lipolysis by milk fat globule membrane materials in model milk fat emulsion. Agric. Biol. Chem., 46 : 795799. 1982.
85) ShIMI2U, M. and K. Y AMAUCH, Isolation and characterization of mucin-like glycoprotein in human milk fat globule membrane. J. Biochem., 91 : 515-524. 1982.

86) Shimizu, M., K. Yamauchi, Y. Miyauchi, T. Sakural, K. TOKUGawa and R.A.J. McIihinney, High-Mr glycoprotein profiles in human milk serum and fat-globule membrane. Biochem. J., 233 : 725-730. 1986.

87) Shmizu, M., K. Yamauchi and M. Saito, Emulsifying properties of the proteose-peptone fraction obtained from bovine milk. Milchwissenshaft, $44: 497-$ 500. 1989.

88）鈴木恵美・東 徳洋・菅野長右ェ門，牛乳プロテォース ペプトン画分の乳化機能. 第 83 回日本畜産学会大会講 演要旨, pp. 195. 1990.

89) SWOPE, F.C., K.C. RHEE and J.R. BRUNNER, The isolation and partial characterization of a fat globule membrane glycoprotein. Milchwissenshaft, $23: 744-$ 746. 1968 .

90) Takamizawa, K., M. I wamori, M. Mutai and Y. NAGAI, Gangliosides of bovine buttermilk. Isolation and characterization of a novel monosialoganglioside with a new branching structure. J. Biol. Chem., 261 : 5625-5630. 1986.

91）高見沢康太郎，人乳・牛釈およびヤギ乳のガングリオシ ト組成の特徽之細菌毒素に対す万給合特性. 酪農科学・ 食品の研究，37:A-259-273. 1988.

92) Thompson, M.P. and J.R. Brunner, The carbohydrates of some glycoproteins of bovine milk. J. Dairy Sci., 42 : 369-370. 1959.

93) Whitney, R.M., J.R. BRUNner, K.E. EBneR, H.M. Farrell, Jr, R.V. Josephson, C.V. MORr and H.E. SWAISGOOD, Nomenclature of the proteins of cow's milk. Fourth revision. J. Dairy Sci., $59: 795-815$. 1976.

94) Wooding, F.B.P. and P. KEMP, Ultrastructure of the milk fat globule membrane with and without triglyceride. Cell Tiss. Res., $165 ; 113-127.1975$.

95) Yamauchi, K., M. Shimizu and C. KanNo, Effect of preparation on properties of a soluble glycoprotein fraction of milk fat globule membrane. J. Dairy Sci., 61 : 688-696. 1978. 